\title{
Pancreatic Exocrine Neoplasm
}

National Cancer Institute

\section{Source}

National Cancer Institute. Pancreatic Exocrine Neoplasm. NCI Thesaurus. Code C4445.

A benign or malignant neoplasm that arises from the epithelial cells of the exocrine pancreatic tissue. 